\title{
A SPORTÁGAZAT NEMZETGAZDASÁGI JELENTŐSÉGÉNEK VIZSGÁLATA BESZÁMOLÓ ADATOK ALAPJÁN 2014-2016-OS IDŐSZAKBAN
}

\author{
Bácsné Bába Éva - Fenyves Veronika - Szabados György - Dajnoki Krisztina - \\ Müller Anetta - Bács Zoltán
}

\begin{abstract}
Absztrakt: Kutatási célunk a magyar sportszolgáltatási piac kínálati oldalának gazdasági elemzése volt nemzetgazdasági ágazati szinten. A kutatás indokoltságát az adja, hogy a legutóbbi hivatalos ágazati adatok a sportszektorról 2012-ben láttak napvilágot. Ezek az adatok arról tanúskodnak, hogy a magyar sportszektor jelentős gazdasági potenciállal rendelkezik, bár még arányaiban elmarad a nyugati országokétól. A sportszektor fejlődésének igazolására tettünk kísérletet az EFOP-3.6.2-162017-00003 projekt keretében beszerzett számviteli beszámoló adatokat tartalmazó adatbázis elemzésével. Az adatbázis a TEÁOR szám (931) szerint főtevékenységként sporttevékenységet üző nonprofit- és profitorientált szervezetek adatait tartalmazza 2014-2016-os időszakban. A vizsgálat korlátja volt, hogy különösen a nonprofit sportszervezetek hiány adatközlése volt, így a szektor teljesítménye csak becsülhető. A vizsgálatok eredményeiből azonban megállapítható, hogy a szektor fejlődése egyértelmü, hozzájárulása a bruttó hozzáadott értékhez mind összegében, mind arányaiban növekedést mutat.
\end{abstract}

Abstract: The purpose of our research was the economic analysis of the Hungarian sport service market's supply-side on a national economic sector level. The main reason for making this study was that the latest published official datas from the sport sector are from 2012. These datas conclude that the Hungarian sport sector possess great potential, although still falls short from western countries. We made an attempt to prove the development of the sport sector by analysing the database containing accounting reports collected within the framework of EFOP-3.6.2-16-2017-00003 project. The database contains datas from nonprofit and profit-oriented organizations with main activity as sport activity (TEÁOR number 931) from the period between 2014-2016. Our research was hindered by the fact that nonprofit sport organizations published incomplete data, so the performance of the sector is merely an estimation. The implication from this study is that the development of the sector is clearly present, and its contribution to the gross added value both in amount and in proportion shows great increase.

Kulcsszavak: sportágazat, nonprofit- és profitorientált sportszervezetek, hozzájárulása a bruttó hozzáadott értékhez

Keywords: sportsector, nonprofit and profit-oriented sports organizations, contribution to the gross added value

\section{Bevezetés}

A globális sportpiac éves átlagos növekedési üteme 2009 és 2013 között 7 \%-os volt, ami azt jelenti, hogy az ágazat növekedési üteme meghaladja a GDP növekedési ütemét a nemzetgazdaságok jelentős hányadában, különösen a nagy piacokon, például az Egyesült Államokban, Brazíliában, az Egyesült Királyságban és Franciaországban.

Az ágazat hosszú távú kilátásai is biztatóak. A háztartások sporteszköz-, ruházat-, felszerelés-, valamint egészségügyi- és fitnesz-kiadásai elérik az évi 700 milliárd dollárt, vagyis a globális GDP 1\%-át (Collignon, 2014). 
Az Európai Unióban a sport közvetlen hatásai és a multiplikátor (közvetett és indukált) hatások együttesen 2,98\%-kal (294,36 milliárd euró) járultak hozzá a teljes bruttó hozzáadott értékhez. A sportágazat nemzeti jövedelem rugalmassága 1,14, ami azt jelenti, hogy ha a nemzeti jövedelem 1\%-kal nő, a sporthoz kapcsolódó bruttó hozzáadott érték 1,14\%-kal emelkedik. Az eredmények kapcsán ki kell emelni, hogy ezek átlag-adatok, amelyek jelentős különbségeket mutatnak a nagy jövedelmü nyugat-európai tagállamok és az alacsonyabb jövedelmü keleti államok között. Abszolút értelemben a sportágazat esetében az egy före jutó bruttó hozzáadott érték a keleti tagállamokban körülbelül 5 euróról 10 euróra nőtt, míg a magasabb jövedelmü államokban ez az összeg 50 euróról 100 euróra emelkedett egy före vetítve. Az, hogy a gazdagabb országok többet költenek a sportra, mint a szegényebb országok természetes, és ez nem csak abszolút, de relatív értelemben is kifejezhető, azaz a sport bruttó hozzáadott értékének aránya alacsonyabb az alacsony jövedelmü EU-tagállamokban a magas jövedelmü tagállamokhoz képest. Az EU egészére nézve a sporthoz kötődő foglalkoztatás teljes foglalkoztatási aránya 2,12\% (EU, 2012).

Magyarország esetében 2012-ben a sportszolgáltatások 778 millió Euróval járultak hozzá a bruttó hozzáadott értékhez, ami arányaiban azt jelenti, hogy az 1\%ot sem éri el az ágazat részesedése. A sport-munkahelyeken foglalkoztatottak száma több, mint 55 ezer fö volt. A sportcikkek piaci volumene 307 millió Eurót ért el, míg az egy főre eső sportcikk vásárlások összege mindössze 30 Euró volt (EU, 2012).

Az 1. táblázat a sportágazat, sportpiac tekintetében legjelentősebb öt tagország és Magyarország adatait tartalmazza.

1. táblázat: A sportágazat részesedése a hozzáadott értékben, és a foglalkoztatásban, valamint a sportcikk-piac volumene és az egy före eső sportcikk vásárlás a sportágazat tekintetében az öt legjelentősebb EU tagállamban és Magyarországon

\begin{tabular}{|l|l|l|l|l|}
\hline Tagállam & $\begin{array}{l}\text { Sportágazat } \\
\text { részesedése a } \\
\text { hozzáadott } \\
\text { érékben } \\
\text { (millió Euró) }\end{array}$ & $\begin{array}{l}\text { Sportágazatban } \\
\text { alkalmazottak } \\
\text { száma (fó) }\end{array}$ & $\begin{array}{l}\text { Sportcikk- } \\
\text { piac } \\
\text { volumene } \\
\text { évente } \\
\text { (millió Euró) }\end{array}$ & $\begin{array}{l}\text { Egy före eső } \\
\text { sportcikk } \\
\text { vásárlás } \\
\text { összege } \\
\text { (Euró) }\end{array}$ \\
\hline $\begin{array}{l}\text { Egyesültt } \\
\text { Királyság }\end{array}$ & 39860 & 632400 & 9000 & 149 \\
\hline Franciaország & 21607 & 416537 & 8709 & 143 \\
\hline Németország & 46677 & 1146234 & 7129 & 86 \\
\hline Olaszország & 15599 & 329860 & 7638 & 130 \\
\hline Spanyolország & 10407 & 336177 & 5313 & 121 \\
\hline Magyarország & 778 & 55577 & 307 & 30 \\
\hline
\end{tabular}

Forrás: Saját szerkesztés Study on the Contribution of Sport to Economic Growth and Employment in the EU, (2012) alapján

Hazánkban az ágazat fejlődése nem a fejlett piacgazdaságú országok példáját követte. A rendszerváltást követően ,az általános közvélekedés az volt, hogy a piac, 
a demokratizálódás, a civil szervezetek megerősödése az állammal szemben automatikusan megteremtik a jóléti társadalom formáit és mindennapos tartalmát" (Bakonyi, 2004). Ám ez a valóságban nem teljesen az elképzeltek szerint ment végbe. A sportszektort ekkor a sportszakma önszerveződésének hiánya, gyenge érdekérvényesítése, és a kormányzati szinten nem kellően átgondolt sportirányítás mellett a krónikus tőkehiány jellemezte. Ez szükségessé tette a magyar sport radikális átalakítását (Szegnerné, 2014). A megújulásra tett erőfeszítéseket a „sporttörvények” tükrözik. A sportfinanszírozásban pedig a hagyományos civil és a megjelenő profitorientált sportszervezetek mellett az állami szerepvállalás is nagy hangsúlyt kapott. A kormányzat sport melletti elköteleződését mutatja, hogy a sport nemzetgazdasági stratégiai ágazattá vált. A hazánkban relatíve kevés potenciális szponzorációra hajlandó és képes vállalati szereplő pótlására a kormányzat az EU bírálatokkal szemben is elérte a társasági adókedvezmény bevezetését, amely jelentősen javította a látvány csapatsportok finanszírozását. Emellett a kormányzati tervek szerint 32 stadion-beruházás valósul meg 2020-ig. A magyar sportágazat rendszerváltást követő fejlődéstörténetét a szektor felzárkózási kísérletei jellemzik. Összességében a magyar sportágazat még elmarad a nyugati példáktól, de igény és igyekezet is van a fejlesztésre. Ennek fényében a sportszolgáltató ágazat további növekedését, modernizációját prognosztizálhatjuk.

A témaválasztás aktualitását az adja, hogy a magyar sportágazat fejlődik, gazdasági súlya nő, aminek kimutatása is szükséges, hiszen a legutóbbi hiteles adatok 2012-ből származnak.

Az ágazat nemzetgazdasági szintü vizsgálatait az „EFOP-3.6.2-16-2017-00003 Sport- Rekreációs és Egészséggazdasági Kooperációs Kutatóhálózat létrehozása" projekt keretében beszerzett adatbázis vizsgálatára alapozom. Az adatbázis a TEÁOR szám szerint sporttevékenységet végző (931) szervezetek legutóbbi három lezárt gazdasági évének számviteli beszámolóadatait tartalmazza. Az elemzés lehetővé teszi az ágazat jelenlegi helyzetének, súlyának megítélését.

\section{Szakirodalmi áttekintés}

A professzionális sport vizsgálatának elméleti alapvetését közgazdasági megközelítésből Dénes, vállalatgazdasági fókuszálással András (2003), és sportjogi irányultságból Sárközy (2002) végezte el.

Dénes (2015) kifejti, hogy a sport „valós” gazdasági jelentősége hogyan mutatható ki. A 2000-es évek elején merült fel az igény arra, hogy az „Európai Unió egészére készüljön egységes módszertan alapján kiterjesztett számbavétel a sportot illetően. A 2006-ban alakult „,Sport és gazdaság” munkacsoport (EU Working Group "Sport \& Economics") a sport ágazat százalékban kifejezett GDP-hez való hozzájárulásának és a sport a foglalkoztatásra és vásárlóerőre gyakorolt hatásának, a sport szektor hosszú távú dinamikájának mérését, illetve a sport szektor érintő, a jövőbeli döntéshozatalt megalapozó megbízható adatok gyüjtését tüzte ki célul. A bizottság a sport makrogazdasági súlyának elméleti kérdéseivel foglalkozott, a sportstatisztikai mérési és módszertani problémák egységes európai kezelésére tett kísérletet. 2007-ben az munkabizottság javaslatot tett a sporttermelés (a sporttal 
kapcsolatos termékek és szolgáltatások, fizikai aktivitások és szabadidő eltöltés) hagyományos értelmezésén és számbavételen túllépő tágabb fogalmi rendszerének egységesen értelmezett kialakítására. Ez a sport „Vilniusi meghatározása”. A meghatározás különbséget tesz a sport statisztikai, szük és átfogó definíciója között: A statisztikai meghatározás csak a „sportesemények”-et sorolja a sportágazat kategóriájába. Szűken értelmezve viszont a statisztikai meghatározás mellett ide sorolnak minden olyan tevékenységet, amely a sporthoz/sportoláshoz szükséges. A tágan/átfogóan értelmezett definíció tovább bővíti az ide tartozó tevékenységeket, hiszen a szük meghatározáson felül magába foglal minden olyan tevékenységet, amelyben a sport, mint bemenet jelenik meg (azaz minden sporteseményhez kapcsolódó, illetve sportoláshoz szükséges termék és szolgáltatás előállítása)" (Dénes, 2015).

„Az egységek gazdasági tevékenységek szerinti osztályozása a hozzáadott érték elvén alapul. A hozzáadott értéket úgy határozhatjuk meg, mint termelési érték és a folyó termelő felhasználás különbsége. Másként a hozzáadott érték a termelési érték, és a felhasznált anyagok, energiák, félkész termékek, valamint az igénybe vett szolgáltatások (beleértve a számviteli rend szerinti egyéb szolgáltatásokat) és a termék, szolgáltatás értékesítéséhez kapcsolódó fogyasztási és jövedéki adók különbsége. Egyszerübben megfogalmazva, a hozzáadott érték konkrét vállalkozás esetében az árbevétel és a vásárolt áruk vagy szolgáltatások értékének különbsége. Egy sportszervezet tevékenységének hozzáadott értéke azt mutatja, hogy a klub tevékenységrendszerével mennyiben járult hozzá a magyar bruttó hazai termékhez (GDP).

A KSH gazdasági tevékenységen azt érti, amikor egy gazdasági szereplö, esetünkben egy sportszervezet, a rendelkezésére álló erőforrások felhasználásával (játékosok, csarnok bérlet, kommunikáció stb.) szolgáltatást nyújt.

Amikor egy sportszervezet tevékenységének teljes hozzáadott értékét vizsgáljuk, tulajdonképpen arra keressük a választ, hogy az alapszolgáltatás, az egyes mérkőzések előállításához milyen termékekre és szolgáltatások igénybevételére van szükség, illetve ezek a mérkőzések milyen más gazdasági tevékenységek számára jelentenek fontos inputot" (Dénes, 2015).

\section{Anyag és módszer}

Kutatási célunk az volt, hogy ágazati szinten a sportvállalkozások hozzáadott értékének, foglalkoztatásra és vásárlóerőre gyakorolt hatását kimutassam, a szervezetek társasági forma, profitorientáltság és szervezeti méret szerinti tipizálását végrehajtsam.

A minta az „EFOP-3.6.2-16-2017-00003 Sport- Rekreációs és Egészséggazdasági Kooperációs Kutatóhálózat létrehozása” projekt keretében beszerzett adatbázisból származott.

A kutatási célkitüzés megfogalmazásakor úgy terveztük, hogy mind a profitorientált, mind a nonprofit/civil sportszervezetek gazdasági teljesítményét külön-külön, illetve együttesen megállapítjuk. A terv azonban csak részben vált megvalósíthatóvá. Az adatbázis valóban tartalmazza a TEÁOR szám (931) szerint 
főtevékenységként sporttevékenységet üző szervezetek adatait. Az adatbázisban szereplő 3066 gazdasági társaságból 2832 jelenleg működő sportvállalkozás esetében rendelkezésre állnak a 2014, 2015, és 2016 lezárt üzleti évre vonatkozó beszámoló adatok, vagyis ezek a szervezetek vizsgálhatóak.

A sportcivilekkel kapcsolatban azonban, az összegyüjtött 12119 szervezetböl csak 11369 rendelkezik érvényes adószámmal. Ám ezen szervezetek összehasonlító vizsgálata nem kivitelezhető, mivel a civilszervezetek adatközlései hiányosak, sok esetben 1998-as közlésủek, illetve nem pontos értékeket, hanem egyes kategóriákba tartozást (pl. létszám esetében: 0, 1, 2, 3-4, 5-9, 10-19, 20-49 fö stb., illetve árkategória esetén: 0-20 millió között, 21-50 millió Ft között, 51-300 millió Ft között, 301-500 millió Ft között stb.) mutatnak. Ezért a sportcivilek jellemzéséhez a KSH nonprofit szervezetekre vonatkozó adatait mutatom be.

Az adatokat statisztikai és gazdasági elemző módszerekkel dolgoztuk fel.

\section{Eredmények}

A 2. táblázat a nonprofit/civil sportszervezetek számát, összes bevételét és az egy szervezetre eső átlagos bevételt mutatja a KSH 2016-os adatai szerint.

\section{2. táblázat: A sport tevékenységü nonprofit szervezetek árbevétele 2016-ban}

\begin{tabular}{|c|c|c|c|c|c|c|c|c|}
\hline \multicolumn{2}{|c|}{ Alapítványok } & \multicolumn{2}{|c|}{$\begin{array}{l}\text { Társas nonprofit } \\
\text { szerv. }\end{array}$} & \multicolumn{2}{|c|}{ Összesen } & \multirow{2}{*}{$\begin{array}{l}\text { Összes } \\
\text { bevétel } \\
\text { (millió Ft) }\end{array}$} & \multirow{2}{*}{$\begin{array}{l}\text { Meg- } \\
\text { oszlás } \\
(\%)\end{array}$} & \multirow{2}{*}{$\begin{array}{l}\text { Egy szerv.- } \\
\text { re jutó } \\
\text { bevétel, } \\
\text { (ezer Ft) }\end{array}$} \\
\hline száma & meg\% & száma & meg\% & száma & meg\% & & & \\
\hline 809 & 3,9 & 8090 & 19,7 & 8899 & 14,4 & 241335,5 & 14,6 & 27119 \\
\hline
\end{tabular}

A profitorientált szervezetek vizsgálatához megfelelőnek bizonyult az adatbázis. A sportvállalkozások gazdasági formájukat tekintve közkereseti társasági, betéti társasági, korlátolt felelösségủ társasági és részvénytársasági formában müködnek. A vállalkozások döntő többsége $(79,76 \%)$ a Kft. formát preferálja (1. ábra). A Kftk között 23 nonprofit, közhasznú kft. is van.

\section{1. ábra: A sportvállalkozások megoszlása gazdasági társasági formájuk szerint} 2016-ban

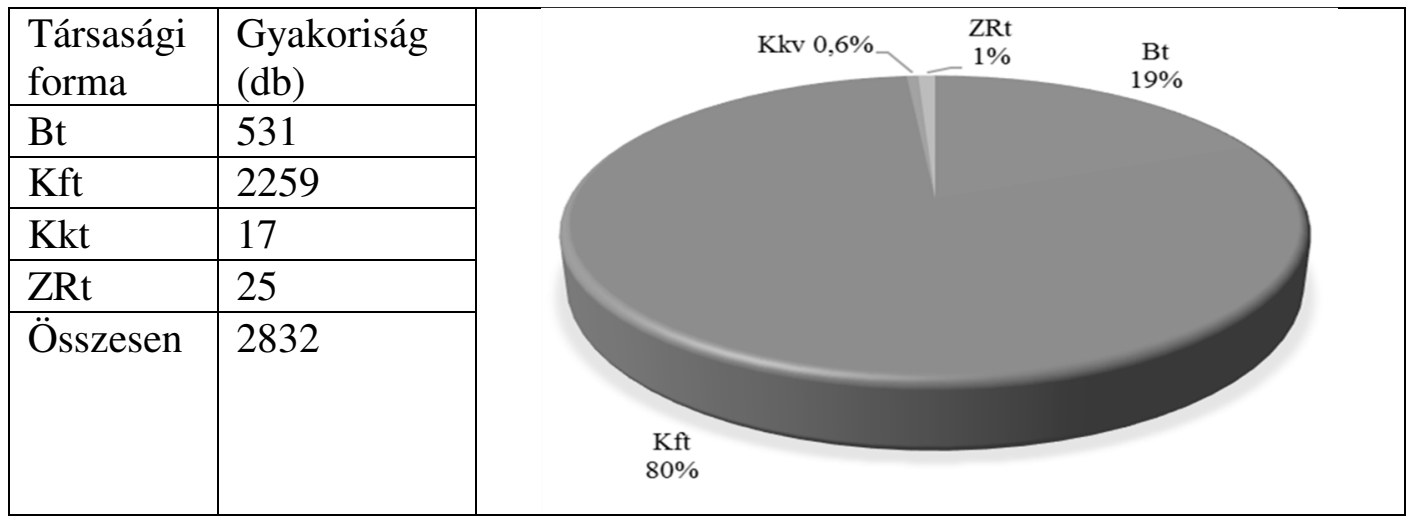


A foglalkoztatotti létszám a szervezetek megoszlását követve szintén a kft-knél a legmagasabb, és a vizsgált időszakban dinamikus növekedést mutat: 2015-re 10,0\%, 2016-ra 14,42\% a növekedés mértéke. Az Rt-k hasonló létszám növekedést értek el arányában $(9,66 \%$ és15,19\%), bár állományi létszámuk számszerüen a kftkének a tizede.

\section{2. ábra: A sportvállalkozások létszám adatai gazdasági társasági formájuk} szerint 2016-ban

\begin{tabular}{|l|l|l|l|l|}
\hline $\begin{array}{l}\text { Társasá- } \\
\text { gi forma }\end{array}$ & $\begin{array}{l}\text { Létszám } \\
\text { (fó) } 2014\end{array}$ & $\begin{array}{l}\text { Létszám } \\
\text { (fó) } 2015\end{array}$ & $\begin{array}{l}\text { Létszám } \\
\text { (fó) } 2016\end{array}$ & \multirow{2}{*}{ Kkt ZRt Bt } \\
\hline $\mathrm{Bt}$ & 225 & 210 & 218 \\
\hline $\mathrm{Kft}$ & 6661 & 7328 & 8385 \\
\hline $\mathrm{Kkt}$ & 12 & 12 & 16 & \\
\hline ZRt & 600 & 658 & 758 & \\
\hline Összesen & 7498 & 8208 & 9377 & $\mathrm{Kft}$ \\
\hline
\end{tabular}

Forrás: Saját szerkesztés

A létszám adatok tekintetében megállapítható, hogy a sportvállalkozásokban összesen minimálisan 9377 dolgoznak. A minimum kitétel alkalmazását alátámasztja, hogy a vizsgált időszak mindhárom évében másfélezernél több szervezet nem közölte alkalmazottai számát (3. táblázat).

\section{3. táblázat: Sportvállalkozások összesített létszám adatai 2014-2016.}

\begin{tabular}{|l|l|l|l|}
\hline & 2014 & 2015 & 2016 \\
\hline Ismert létszám (fö) & 7498 & 8208 & 9377 \\
\hline $\begin{array}{l}\text { Szervezetek száma, ahol } \\
\text { hiányzik az adat (db) }\end{array}$ & 1703 & 1619 & 1500 \\
\hline
\end{tabular}

Forrás: Saját szerkesztés

A sportvállalkozások tipizálási lehetősége a létszám adatok alapján lehetséges. Amint a 4. táblázat mutatja a sportvállalkozások a kkv szektor reprezentánsai, azon belül is leginkább mikro, és kisvállalatok. A középvállalati méretet csupán néhány részvénytársaság és kft. éri el a mintában.

4. táblázat: Sportvállalkozások kategorizálása alkalmazotti létszám (méret) alapján 2014-2016.

\begin{tabular}{|l|l|l|l|}
\hline$($ db $)$ & 2014 & 2015 & 2016 \\
\hline Mikro (<10 fö) & 775 & 1041 & 1129 \\
\hline Kis $(<50$ fö) & 128 & 148 & 176 \\
\hline Közép (<250 fö) & 25 & 24 & 27 \\
\hline Összes ismert & 928 & 1213 & 1332 \\
\hline Nincs adat & 1703 & 1619 & 1500 \\
\hline Összes müködő & 2631 & 2832 & 2832 \\
\hline
\end{tabular}

Forrás: Saját szerkesztés 
Az adatbázis lehetővé teszi a sportvállalkozások együttes bruttó hozzáadott értékének meghatározását. A meghatározás egyetlen kérdéses eleme a „termék, termelési támogatások" értéke. A probléma abból adódik, hogy ezen támogatások az „egyéb bevételek” közt jelennek meg, de nem külön soron. Emiatt pontos értékük nem állapítható meg, mivel az „egyéb bevételek” kategóriába további gazdasági események hatását is szerepeltetni kell (pl. eladott tárgyi eszközök könyv szerinti értéke stb.). Mivel ezek a támogatások - feltéve, ha vannak ilyenek - a hozzáadott értéket növelik, a nélkülük megállapított hozzáadott értéknél a valóságos hozzáadott érték csak magasabb összegủ lehet, ezért a számítások eredményeként a hozzáadott érték „,minimális” összegét kapjuk meg. Az 5. táblázat szerint a 2014-2015-2016-os éveket vizsgálva megállapítható, hogy a sportvállalkozások hozzáadott értéke folyamatos emelkedést mutat. A hozzáadott érték volumenindexe a vizsgált időszakban: 2015-ben 108,97\%, 2016-ban 119,57\% volt az előző évhez viszonyítva.

\section{5. táblázat: A sportvállalkozások együttes hozzáadott értékének megállapítása}

2014-2016.

\begin{tabular}{|l|l|l|l|}
\hline & $\begin{array}{l}2014 \\
(\mathrm{eFt})\end{array}$ & $\begin{array}{l}2015 \\
(\mathrm{eFt})\end{array}$ & $\begin{array}{l}2016 \\
(\mathrm{eFt})\end{array}$ \\
\hline + nettó árbevétel & 78239590 & 88873261 & 105776121 \\
\hline $\begin{array}{l}\text { + saját elöállítású } \\
\text { eszközök aktivált } \\
\text { értéke }\end{array}$ & 35439 & 61065 & 59473 \\
\hline $\begin{array}{l}\text { - eladott áruk } \\
\text { beszerzési értéke } \\
\text { (ELÁBÉ) }\end{array}$ & 272891 & 301959 & 309091 \\
\hline $\begin{array}{l}\text { - közvetített } \\
\text { szolgáltatások }\end{array}$ & 1183619 & 1620498 & 1750597 \\
\hline $\begin{array}{l}\text { + saját termelésü } \\
\text { készletek } \\
\text { állományváltozása }\end{array}$ & 50863 & 1234 & 3812 \\
\hline $\begin{array}{l}\text { - anyag és energia } \\
\text { költség }\end{array}$ & 2208672 & 2434980 & 2801818 \\
\hline $\begin{array}{l}\text { - igénybe vett } \\
\text { szolgáltatások }\end{array}$ & 18877644 & 23815812 & 28286886 \\
\hline $\begin{array}{l}\text { - egyéb } \\
\text { szolgáltatás }\end{array}$ & 372655 & 380226 & 490387 \\
\hline $\begin{array}{l}\text { + termék } \\
\text { termelési } \\
\text { támogatások }\end{array}$ & 55410411 & 60382085 & 72200627 \\
\hline $\begin{array}{l}\text { = Bruttó } \\
\text { hozzáadott érték }\end{array}$ & & & \\
\hline
\end{tabular}

Forrás: Saját szerkesztés 
A profitorientált sportvállalkozások együttes hozzájárulását a hazai hozzáadott értékhez a 6. táblázat tartalmazza. Eszerint a profitorientált sportszektor hozzáadott értékhez való hozzájárulásának mértéke 214-2015-ben 0,17\%, 2016-ban 0,20\% volt.

6. táblázat: Hozzáadott érték a sportvállalkozásoknál összesen 2016-ban

\begin{tabular}{|c|c|c|c|c|}
\hline & & 2014 & 2015 & 2016 \\
\hline \multirow[t]{2}{*}{$\begin{array}{l}\text { Nemzet- } \\
\text { gazdaság }\end{array}$} & $\begin{array}{l}\text { Hozzáadott } \\
\text { érték (mFt) }\end{array}$ & 32591700 & 34324100 & 35420300 \\
\hline & $\begin{array}{l}\text { Hozzáadott É. } \\
\text { volumenindex }\end{array}$ & 104,2 & 103,4 & 102,2 \\
\hline \multirow{5}{*}{$\begin{array}{l}\text { Profit- } \\
\text { orientált } \\
\text { Sport } \\
\text { szektor }\end{array}$} & $\begin{array}{l}\text { Árbevétel } \\
(\mathrm{mFt})\end{array}$ & 78239,590 & 88873,261 & 105776,121 \\
\hline & $\begin{array}{l}\text { Hozzáadott } \\
\text { érték }(\mathrm{mFt})\end{array}$ & 55410,411 & 60382,085 & 72200,627 \\
\hline & $\begin{array}{l}\text { Hozzáadott É. } \\
\text { (mEuróban)* }\end{array}$ & 179,519 & 194,843 & 231,813 \\
\hline & $\begin{array}{l}\text { Hozzáadott É. } \\
\text { volumenindex }\end{array}$ & & 108,9 & 119,5 \\
\hline & $\begin{array}{l}\text { Hozzájárulás a } \\
\text { Hozzáadott É.- } \\
\text { hez }\end{array}$ & $0,1700 \%$ & $0,1759 \%$ & $0,2038 \%$ \\
\hline
\end{tabular}

(*Euro éves átlag árfolyama 308,66Ft/Euro 309,90Ft/Euro; 311,46Ft/Euro) Forrás: Saját szerkesztés

A sportszektor esetében 2016 vonatkozásában a profitorientált és nonprofit szervezetek együttes árbevétele állapítható meg, ami 419312 millió Ft, azaz 1346,278 millió Euro. (A sportvállalkozások esetében a hozzáadott érték mindhárom vizsgált évben az árbevétel $70 \%$ körül mozgott. Ha ezt az arányt feltételezzük a nonpofit sportszervezetekre is, akkor a sportszektor becsült hozzáadott értéke 293 518 millió Ft, azaz 942,395 millió Euro körül mozoghat.)

A sportcikk piac forgalmára vonatkozó adatokat a KSH adatbázisa biztosította. Eszerint a sportcikk piac volumene a vizsgált időszakban: 128 421, 139486 és 154 717 millió Ft, azaz 416, 450 és 496 millió Euro volt. Az egy főre eső sportfogyasztás: 42 Euro, 45 Euro, 50 Euro volt a vizsgált időszak egymást követő éveiben.

A 2012-es tanulmány adatait a 7. táblázatban hasonlítom össze az általam megállapított értékekkel. Mivel a táblázat egyetlen ponton hiányos - a sportágazat foglalkoztatotti létszámánál - kísérletet teszek ennek a meghatározására is. Bár a vizsgálat elején jeleztük, hogy a sportcivilek adatai nem megfelelőek a vizsgálatokhoz, mégis az érvényes adószámúak viszonylatában felmérjük az alkalmazottak létszámát. 
7. táblázat: A sportágazat részesedése a hozzáadott értékben, és a foglalkoztatásban, valamint a sportcikk-piac volumene és az egy före eső sportcikk vásárlás Magyarországon2012-ben és 2016-ban

\begin{tabular}{|l|l|l|l|l|}
\hline & $\begin{array}{l}\text { Sportágazat } \\
\text { részesedése a } \\
\text { hozzáadott } \\
\text { értékben } \\
\text { (millió Euró) }\end{array}$ & $\begin{array}{l}\text { Sportágazatban } \\
\text { alkalmazottak } \\
\text { száma (fö) }\end{array}$ & $\begin{array}{l}\text { Sportcikk- } \\
\text { piac } \\
\text { volumene } \\
\text { évente (millió } \\
\text { Euró) }\end{array}$ & $\begin{array}{l}\text { Egy före eső } \\
\text { sportcikk } \\
\text { vásárlás } \\
\text { összege } \\
\text { (Euró) }\end{array}$ \\
\hline 2012 & 778 & 55577 & 307 & 30 \\
\hline 2016 & 942 & $?$ & 496 & 50 \\
\hline
\end{tabular}

Forrás: Saját szerkesztés

\section{8. táblázat: Sportcivil szervezetek létszám adatai 2016-ban}

\begin{tabular}{|l|l|}
\hline $\begin{array}{l}\text { Sportcivilek } \\
\text { létszám (fö) }\end{array}$ & $\begin{array}{l}\text { zzervezetek } \\
\text { száma }(\mathrm{db})\end{array}$ \\
\hline 0 fö & 8545 \\
\hline 1 fö & 684 \\
\hline 2 fö & 266 \\
\hline $3-4$ fö & 180 \\
\hline $5-9$ fö & 141 \\
\hline $10-19$ fö & 78 \\
\hline $20-49$ fö & 41 \\
\hline $50-99$ fö & 3 \\
\hline $100-149$ fö & 3 \\
\hline $200-249$ fö & 1 \\
\hline $250-299$ fó & 1 \\
\hline Nincs adat & 1426 \\
\hline Összesen & 11369 \\
\hline
\end{tabular}

Forrás: saját szerkesztés

A 8. táblázat adatai alapján a sportcivileknél foglalkoztatottak száma 4961 és 7988 fő között mozoghat. Ha a minimum értékhez szeretnék igazodni ebben a tekintetben is, akkor a sportvállalkozásoknál foglalkoztatottakkal együttesen a sportszektorban dolgozók számát 14338 före tehetjük. Ha eltérve a minimum kitételtől a maximum ismert adatot veszem figyelembe, akkor 17365 fö az eredmény. Ezek az adatok azonban annyira elütnek a 2012-es kiinduló értéktől (55 577 fö), és a becsült érték annyira sok bizonytalanságot tartalmaz, hogy az értékeket nem tartjuk alkalmasnak a vizsgált tényező, a foglalkoztatottak számának jellemzésére.

\section{Következtetések}

A sportszektor nemzetgazdasági szintü elemzését csak részlegesen tudtuk megvalósítani, mivel az adatbázis a profitorientált sportvállalkozások elemzését tette 
lehetővé. A teljes kép kialakításához a nonprofit sportszervezetekről a $\mathrm{KSH}$ adatbázisából informálódtunk.

A profitorientált sportszektorban dominánsak a kft. formában müködö gazdasági társaságok. Ezek a szervezetek alkalmazzák a szektorban dolgozók többségét. A foglalkoztatotti létszám évről évre dinamikusan növekszik, 2016-ban minimálisan 9377 föt alkalmaztak a sportvállalkozások. A szektor vállalkozásait méret alapján kategorizálni lehetett. Eszerint a profitorientált társaságok a kkv-k táborába tartoznak, azon belül is mikro- és kisvállalkozások döntően.

A profitorientált sportszervezetek hozzáadott értékét sikerült megállapítani. A három egymást követö évben 55 410, 60 382, 72200 millió Ft volt. Ezek a szervezetek a nemzetgazdasági hozzáadott értékhez 214-2015-ben 0,17\%-kal, 2016ban 0,20\%-kal járultak hozzá.

A sportszektor esetében 2016 vonatkozásában a profitorientált és nonprofit szervezetek együttes árbevétele volt megállapítható, ami 419312 millió Ft, azaz 1346,278 millió Euró volt. A sportvállalkozások esetében a hozzáadott érték mindhárom vizsgált évben az árbevétel 70\% körül mozgott. Ezt az arányt igaznak feltételezve a sportcivilekre, a sportszektor becsült hozzáadott értéke 293518 millió Ft, azaz 942,395 millió Euró körül mozoghat.

A sportcikk piac volumene a vizsgált időszakban: 128 421, 139486 és 154717 millió Ft, azaz 416, 450 és 496 millió Euro volt. Az egy före eső sportfogyasztás: 42 Euro, 45 Euro, 50 Euro volt a vizsgált időszak egymást követő éveiben.

Az utolsó, 2012-benközölt adatokhoz képest mind a sportágazat becsült hozzáadott értéke (778 mEuróról $942 \mathrm{mEuróra),} \mathrm{mind} \mathrm{a} \mathrm{sportcikk} \mathrm{piac} \mathrm{volumene}$ (307 mEuróról 496 mEuróra), mind az egy főre eső sportcikk vásárlások összege (30 Euróról 50 Euróra) növekedett.

A vizsgálat korlátja, a különösen a nonprofit sportszervezeteket jellemző hiányos, elmulasztott adatközlés, illetve az, hogy a létszám és árbevétel adataikat nem összegszerủen, hanem kategóriákba sorolva adják meg. Amíg ez így marad a szektor teljesítménye csak megbecsülhetö.

\section{6. Összefoglalás}

Kutatási célunk a magyar sportszolgáltatási piac kínálati oldalának gazdasági elemzése volt nemzetgazdasági ágazati szinten.

A kutatás indokoltságát az adja, hogy a legutóbbi hivatalos ágazati adatok a sportszektorról 2012-ben láttak napvilágot. Ezek az adatok arról tanúskodnak, hogy a magyar sportszektor jelentős gazdasági potenciállal rendelkezik, bár még arányaiban elmarad a nyugati országokétól. Felmerül a kérdés, hogy azóta töretlene a sportszektor fejlődése? Ennek igazolására tettünk kísérletet az „EFOP-3.6.2-162017-00003 Sport- Rekreációs és Egészséggazdasági Kooperációs Kutatóhálózat létrehozása" projekt keretében beszerzett számviteli beszámoló adatokat tartalmazó adatbázis elemzésével.

A vizsgálat korlátja, a különösen a nonprofit sportszervezeteket jellemző hiányos, elmulasztott adatközlés volt, illetve az, hogy a létszám és árbevétel 
adataikat nem összegszerủen, hanem kategóriákba sorolva adják meg. Amíg ez így marad a szektor teljesítménye csak becsülhető.

Az, hogy a TEÁOR szám szerint fötevékenységként sporttevékenységgel (931) foglalkozó gazdasági társaságok és egyéb szervezetek beszámoló adatai alapján meghatározható a sportszektor gazdasági súlya így csak részben igazolódott be. Számításaink szerint - amelyek becslést is tartalmaztak - szerint a sportszektor becsült hozzáadott értéke 293518 millió Ft, azaz 942,395 millió Euró körül mozoghat. A három éves időszakot felölelő vizsgálatok eredményeiből egyértelműen látszik, hogy a szektor fejlődése töretlen, hozzájárulása a hozzáadott értékhez mind összegében, mind arányaiban növekedést mutat.

A publikáció elkészítését a EFOP-3.6.2-16-2017-00003 Sport- Rekreációs és Egészséggazdasági Kooperációs Kutatóhálózat létrehozása projekt támogatta.

\section{Irodalomjegyzék}

András K. (2003): A sport és az üzlet kapcsolata - elméleti alapok. BCE Vállalatgazdasági Intézet Mühelytanulmány, Budapest.

Bakonyi T. (2004): Civil álom és politikus állam Adalékok a civil sportszervezetek státuszának legújabb-kori politikatörténetéhez. Magyarországon. PhD disszertáció tézisei. Semmelweis Egyetem Nevelés- és Sporttudományi Doktori Iskola, Budapest.

Collignon, N. S. (2014): Winning in the Business of Sports. Research report A.E. Kerney Global Management Conculting Firm. <https://www.atkearney.com/communications-media-technol ogy/article?/a/winning-in-the-business-of-sports> (2018. 03.13.)

Dénes F. (2015): Sportközgazdaságtan. Campus Kiadó, Debrecen, 2015.

KSH (2017): A nonprofit szervezetek száma, megoszlása és összes bevétele tevékenységcsoportok szerint (2005-), <http://www.ksh.hu/docs/hun/xstadat/xstadat_eves/i_qpg004.html> (2018.03.10.

Sárközy T. (2002): A Sporttörvény magyarázata. HVGORAC Lap- és Könyvkiadó Kft., I. rész, Budapest.

EU (2012): Study on the Contribution of Sport to Economic Growth and Employment in the EU, 2012 $<$ http://ec.europa.eu/assets/eac/sport/library/studies/study-contribution-spors-economicgrowth-final-rpt.pdf $>(2018.03 .13$. $)$

Szegnerné Dancs H. (2014): Magyar sporttörténet. <http://www.tankonyvtar.hu/hu/tartalom/tamop 425/0025_Nadori-Dancs-Retsagi-Ekler-Gaspar-Sportelmeleti_ismeretek/ch06s05.html> (2018.03.13) 